\title{
PENERAPAN MODEL PEMBELAJARAN BERBASIS MASALAH (PBM) GUNA MENINGKATKAN KETERAMPILAN MENULIS TEKS PIDATO PADA MAHASISWA SEMESTER III JURUSAN PENDIDIKAN BAHASA DAN SASTRA INDONESIA
}

\author{
Ida Ayu Md. Darmayanti ${ }^{1}$, I Gd. Nurjaya ${ }^{2}$, I Nengah Martha ${ }^{3}$ \\ Jurusan Pendidikan Bahasa dan Sastra Indonesia, Fakultas Bahasa dan Seni \\ Universitas Pendidikan Ganesha \\ Jalan Jend. A. Yani 67 Singaraja 81116, Telp. 0362-21541, Fax. 0362-27561 \\ Email: dayudarmayanti1984@yahoo.com ${ }^{1}$
}

\begin{abstract}
The design of this study was a classroom action research design that was done by using two cycles. This study is aimed to find out the appropriate learning steps in the problem based learning method that can improve the creativity in writing speech text of the 3rd semester students in Indonesian Language Education Department. The subject of this study were the 3rd semester students in Indonesian Language Education Department. The data of this study were collected by using three instruments, they are observation, interview, and questionnaire. Besides, the result of this study are the effective learning steps related with the creativity in writing a speech text. Not only to improve the creativity in writing speech text for the college students, the appropriate learning steps in problem based learning method can also improve the learning activity of college students in the classroom. That improvement was proven by their responses which show that they are agree with the application of the problem based learning method. Thus, this study suggested the other researchers that observe this kind of topic to be able to research this kind of study from the other aspects.
\end{abstract}

Keywords: Problem Based Learning Method, writing speech text, college students.

\begin{abstract}
ABSTRAK
Rancangan penelitian ini adalah penelitian tindakan kelas yang dilakukan dalam dua siklus. Penelitian ini bertujuan menemukan langkah-langkah pembelajaran dengan model PBM (Pembelajaran Berbasis Masalah) yang tepat yang dapat meningkatkan keterampilan menulis teks pidato pada mahasiswa semester III Jurusan PBSI (Pendidikan Bahasa dan Sastra Indonesia). Subjek penelitian ini adalah mahasiswa semester III Jurusan PBSI. Penelitian yang teknik pengumpulan datanya dilakukan dengan menggunakan teknik observasi, tes, dan angket ini sangat perlu dilakukan karena penerapan model PBM untuk meningkatkan keterampilan menulis teks pidato pada mahasiswa semester III Jurusan PBSI belum dilakukan. Hasil penelitian ini adalah dihasilkan langkah-langkah pembelajaran yang efektif terkait keterampilan menulis teks pidato. Selain dapat meningkatkan keterampilan menulis teks pidato pada mahasiswa, langkah-langkah pembelajaran dengan model PBM yang tepat juga dapat meningkatkan aktivitas belajar mahasiswa di kelas. Peningkatan aktivitas itu didukung oleh respons mahasiswa yang setuju terhadap penerapan model PBM. Adapun saran yang dapat disampaikan adalah peneliti lainnya sangat diharapkan untuk melakukan penelitian mengenai model PBM dari aspek lain yang dianggap penting untuk dikaji.
\end{abstract}

Kata-kata Kunci: PBM, menulis teks pidato, mahasiswa 


\section{PENDAHULUAN}

Setiap manusia pastilah memiliki kemampuan atau keterampilan berbahasa, yakni menulis, baik itu secara intensif maupun amatiran. Menulis merupakan salah satu kegiatan yang bersifat produktif dalam empat keterampilan berbahasa (Tarigan, 1994:3). Kegiatan yang bersifat produktif ini, pada umumnya, mewujudkan karya berupa tulisan. Tulisan yang berkualitas menuntut kualitas pemikiran seseorang, terutama kualitas ide dan kualitas teknik dalam pengungkapan idenya. Abizar (2010:43) juga menyatakan bahwa menulis dengan teknik yang benar dan bermakna menjadi syarat utama dalam upaya mewujudkan seseorang menjadi cerdas menulis. Seseorang, dalam hal ini adalah mahasiswa, memiliki kualitas ide yang baik jika ide tersebut muncul berdasarkan pemikiranpemikiran kritis, masuk akal, dan dapat dibuktikan, berdasarkan data atau fakta-fakta.

Pemunculan pemikiran mahasiswa yang kritis ini perlu diciptakan melalui kegiatan keterampilan menulis, khususnya, keterampilan menulis teks pidato, yang terangkum dalam mata kuliah retorika atau ilmu/seni berbicara. Gagasan kritis mahasiswa merupakan faktor penentu tingkat kualitas teks pidato yang dihasilkan. Teks pidato merupakan sebuah kegiatan berbicara di depan umum dengan menggunakan susunan kata yang baik, bertujuan menyampaikan perasaan, isi hati, pendapat, gagasan, pengalaman, pengetahuan, dan materi suatu perihal kepada orang banyak serta dilakukan berdasarkan kaidah kebahasaan yang baik dan benar.

Selama ini, kualitas keterampilan menulis naskah teks pidato yang dihasilkan oleh mahasiswa masih rendah. Rendahnya kualitas itu dapat dilihat dari 3 hal utama dalam penyusunan naskah teks pidato, yaitu pendahuluan, isi (substansi), dan penutup. Selain itu, mahasiswa belum mampu menggunakan kalimat yang efektif, padahal mereka sudah berada pada semester III. Teknik penulisan mereka tidak sesuai dengan kaidah kebahasaan. Di samping itu, diksi atau pilihan kata yang digunakan salah dari tata bentuk dan monoton dari kevariasiannya. Ini adalah kelemahan-kelemahan tulisan yang dihasilkan oleh mahasiswa semester III Jurusan Pendidikan Bahasa dan Sastra Indonesia (PBSI).

Jurusan Pendidikan Bahasa dan Sastra Indonesia (PBSI) merupakan jurusan yang mumpuni dalam hal menghasilkan mahasiswa yang cerdas dalam menerapkan keterampilan berbahasa, yakni membaca, menulis, menyimak, dan berbicara. Ironis jika mahasiswa tidak memiliki kemampuan menulis yang baik. Mahasiswa tidak mampu menulis teks pidato dengan baik adalah salah satu kegagalan dari tidak dicapainya keterampilan berbahasa. Mahasiswa jurusan PBSI sudah semestinya memiliki kemampuan yang baik dalam menulis sebuah naskah teks pidato.

Berdasarkan data yang dimiliki oleh dosen pengampu mata kuliah Retorika, sebanyak 25\% mahasiswa mampu menulis naskah teks pidato dengan baik dan sebanyak $75 \%$ mahasiswa tidak mampu menulis naskah teks pidato dengan baik. Indikator penilaian yang digunakan oleh dosen pengampu mata kuliah Retorika selama ini adalah penilaian dari segi isi, organisasi tulisan, bahasa, kosa kata, dan teknik penulisan.

Rendahnya kemampuan mahasiswa dalam membuat naskah teks pidato disebabkan oleh kemampuan minim yang dimiliki oleh mahasiswa. Kelemahan itu, antara lain mahasiswa tidak mampu membuat pendahuluan yang baik, penyampaian isi atau substansi yang tidak tepat, organisasi tulisan dan pemakaian bahasa ataupun tata kalimat yang tidak sesuai dengan kaidah kebahasaan, serta tidak terdapatnya penutup pada naskah teks pidato yang dibuat. Akibatnya, mahasiswa tidak dapat melahirkan sebuah tulisan yang baik. Mahasiswa mencoba menawar penugasan itu agar dibuat di rumah dengan jangka waktu yang agak lama. Ini adalah salah satu bentuk kegagalan dalam pembelajaran. Seperti disampaikan oleh Vygotsky (dalam Yelfiza, 2010: 187), belajar sesungguhnya sebagai sebuah proses dinamis antara pendidik dan peserta didik melalui dialog dalam upaya membentuk kebiasaan-kebiasaan dan keterampilan. Dengan kata lain, belajar sesungguhnya 
adalah proses mengalami (Hamali, 2004: 27). Dalam hal ini adalah adanya kebiasaan menulis kritis dan keterampilan menulis kritis. Untuk menstimulasi ide mahasiswa dalam menulis naskah teks pidato, mahasiswa harus distimulasi dengan masalah.

Berdasarkan permasalahan tersebut, penerapan model Pembelajaran Berbasis Masalah (PBM) sangat perlu dilakukan. Menurut Barrows dalam Sadia (2006), Pembelajaran Berbasis Masalah (PBM) memiliki karakteristik, yakni (1) pembelajaran bersifat student-centered, (2) pembelajaran berlangsung dalam kelompok kecil, (3) pendidik berperan sebagai fasilitator atau pembimbing, (4) permasalahan-permasalahan yang disajikan dalam setting pembelajaran yang diorganisasi dalam bentuk fokus tertentu dan merupakan stimulus pembelajaran. Selain itu, PBM memiliki beberapa keunggulan, antara lain penerapan model PBM akan merangsang mahasiswa berpikir kritis sehingga melalui pemikiran kritis tersebut, mahasiswa akan memunculkan karya yang berkualitas dalam tulisan.

PBM menyiapkan mahasiswa untuk berpikir secara kritis dan analitis serta mampu untuk mendapatkan dan menggunakan sumber-sumber pembelajaran secara tepat. Melalui PBM, pembelajaran menjadi lebih bermakna. Berangkat dari masalah yang ada, mahasiswa merespons permasalahan tersebut dengan memikirkan atau menemukan sendiri. Pemecahannya melalui pemikiran tingkat tinggi yang diwujudkan dalam bentuk naskah teks pidato sehingga pembelajaran bagi mahasiswa menjadi lebih bermakna. Melalui PBM, mahasiswa termotivasi untuk belajar. Masalah yang ada akan menstimulasi pemikiran mahasiswa untuk memunculkan ide-ide kritis. Hal ini disebabkan oleh masalah yang diberikan oleh dosen lebih mengarahkan pemikiran mahasiswa. Dengan demikian, penelitian ini memiliki otoritas yang tinggi sebagai sebuah penelitian yang harus dilakukan.

Adapun tujuan penelitian ini adalah (1) untuk menguji atau membuktikan penerapan model pembelajaran berdasarkan masalah dalam pembelajaran keterampilan menulis teks pidato guna meningkatkan aktivitas belajar pada mahasiswa semester III Jurusan PBSI; (2) untuk mendeskripsikan penerapan model pembelajaran berdasarkan masalah dalam pembelajaran keterampilan menulis teks pidato guna meningkatkan kualitas belajar pada mahasiswa semester III Jurusan PBSI; dan (3) untuk mendeskripsikan respons mahasiswa semester III Jurusan PBSI terhadap penerapan model pembelajaran berdasarkan masalah dalam keterampilan menulis teks pidato.

\section{METODE PENELITIAN}

Penelitian ini menggunakan pendekatan Penelitian Tindakan Kelas (PTK). Penelitian Tindakan Kelas (PTK) dilakukan berbasis kelas dan dilakukan di kelas. Pelaksanaan penelitian ini mengolaborasikan peneliti dengan dosen pengampu mata kuliah Retorika. Pembelajaran dan perbaikan pembelajaran akan dilakukan dalam penelitian ini. Oleh karena itu, pelaksanaannya dilakukan secara multisiklus. Subjek penelitian ini adalah mahasiswa semester III kelas A Jurusan PBSI dengan jumlah mahasiswa 15 orang, sedangkan objek penelitian ini adalah mendeskripsikan aktivitas, hasil belajar, dan respons mahasiswa.

Penelitian ini menggunakan empat tahapan, yakni (1) tahap perencanaan (planning), (2) tindakan (action), (3) pengamatan, dan (4) refleksi (reflecting). Penelitian ini dilaksanakan dalam beberapa siklus. Pertama, refleksi awal. Kedua, perumusan perencanaan tindakan. Ketiga, pelaksanaan tindakan I. Pada tindakan ini, observasi dan evaluasi juga dilaksanakan terhadap pelaksanaan tindakan I. Selanjutnya, pemberian angket untuk diisi oleh mahasiswa setelah proses belajar-mengajar selesai. Hal ini dilakukan untuk mengetahui kesan mahasiswa terhadap kegiatan dan pelaksanaan proses pembelajaran tersebut.

Setelah tindakan I selesai, refleksi terhadap tindakan yang sudah dilaksanakan adalah langkah selanjutnya. Apabila hasil yang dicapai oleh mahasiswa pada tindakan I belum memenuhi target, perlu dibuatkan perencanaan untuk tindakan II. Begitu seterusnya 
sampai diperoleh hasil pembelajaran sesuai dengan target.

Penelitian ini menggunakan instrumen penelitian, yaitu lembar observasi, tes hasil belajar, dan angket. Teknik pengumpulan data dilakukan dengan tiga metode, yakni (1) metode observasi, (2) tes, dan (3) metode angket. Pengolahan data dalam penelitian ini menggunakan teknik analisis deskriptif kuantitatif dan kualitatif. Deskriptif kuantitatif digunakan untuk mendeskripsikan hasil penelitian dengan menggunakan angka-angka, sedangkan teknik deskriptif kualitatif digunakan untuk mendeskripsikan hasil penelitian dengan menggunakan kata-kata atau kalimat-kalimat. Data aktivitas belajar mahasiswa dianalisis untuk memperoleh gambaran secara klasikal. Analisis didasarkan pada rata-rata skor aktivitas mahasiswa (X) mean ideal (MI) dan standar deviasi ideal (SDI).

$\mathrm{MI}=1 / 2($ skor tertinggi + skor terendah ideal $)$ $\mathrm{SDI}=1 / 6$ (skor tertinggi ideal - skor terendah ideal) (Nurkancana dalam Abdul, 2007: 54).

Luaran penelitian ini berupa penerbitan dalam bentuk artikel dalam jurnal penelitian ilmiah ber-ISSN. Penerbitan artikel ilmiah ini diharapkan dapat memberikan konstribusi bagi masyarakat akademis di Indonesia dengan pemaparan isi yang lebih singkat, padat, dan lebih jelas.

\section{HASIL DAN PEMBAHASAN}

\section{Hasil Penelitian}

Penelitian ini dilakukan dalam 2 (dua) siklus. Siklus I dilaksanakan pada Rabu, 25 Mei 2016 - Kamis, 26 Mei 2016 dan siklus II dilaksanakan pada Rabu, 1 Juni 2016.

\section{Siklus I}

Penelitian tindakan kelas ini dilaksanakan di kelas A semester III jurusan PBSI. Subjek penelitian ini sebanyak 15 orang. Materi yang dibahas mengenai menulis teks pidato. Siklus I dirancang dalam 2 (dua) rencana pembelajaran.

\section{Hasil Observasi Siklus I}

Penelitian tindakan kelas pada siklus
I ini dilaksanakan dalam dua kali pertemuan, yaitu pada Rabu, 25 Mei 2016 dan Kamis, 26 Mei 2016. Pembelajaran pada pertemuan ke-1 dirancang untuk menyampaikan materi terkait pidato. Sementara itu, pembelajaran pada pertemuan ke-2 lebih diarahkan pada penerapan konsep menulis teks pidato dan mengkritisi informasi yang problematik atau kontradiktif. Aktivitas mahasiswa yang muncul pada pertemuan ke-1 dicatat dalam sebuah instrumen penelitian berupa catatan lapangan. Sementara itu, aktivitas mahasiswa pada pertemuan ke-2 diobservasi dengan pedoman lembar observasi dan catatan lapangan. Lembar pedoman observasi memuat 10 butir aktivitas yang diharapkan dilakukan oleh mahasiswa di kelas. Masing-masing butir aktivitas itu diberi skor 1. Jadi, masing-masing mahasiswa akan memperoleh skor aktivitas maksimal 10 .

Pada pertemuan I siklus I, kegiatan pembelajaran dilakukan dalam tiga kegiatan, yakni kegiatan awal (membuka pembelajaran), kegiatan inti, dan kegiatan akhir (menutup pembelajaran). Selama 15 menit ada empat kegiatan yang dilakukan oleh dosen pada kegiatan membuka pelajaran. Kegiatan pembelajaran pada pertemuan ke-1 ini difokuskan kepada penanaman konsep terkait materi menulis teks pidato, informasi yang problematik atau kontradiktif, serta langkahlangkah menyusun teks pidato dengan pola PBM. Setelah penanaman konsep dilakukan, mahasiswa diberikan konsep mengenai informasi yang problematik atau kontradiktif terlebih dahulu. Selanjutnya, dosen menyampaikan materi menulis teks pidato yang berorientasi pada masalah aktual yang ada.

Setelah 60 menit mengisi kegiatan inti pembelajaran, dosen akhirnya sampai pada kegiatan mengakhiri pembelajaran. Selama kurang lebih 5 menit dosen bersama mahasiswa menyimpulkan materi pembelajaran. Pada kegiatan ini, mahasiswa diberikan kesempatan untuk mengingat kembali materi yang sudah didapat. Kemudian, pada Kamis, 26 Mei 2016, peneliti melanjutkan Siklus I pertemuan ke-2. Pada pertemuan ini, dosen lebih memfokuskan untuk mengajak mahasiswa mengkritisi bacaan dan menuangkan 
pendapat yang lebih kritis itu dalam teks pidato. Berdasarkan pemahaman mahasiswa terhadap materi pembelajaran sebelumnya, dosen berharap mahasiswa dapat membuat teks itu.

Mengawali pertemuan ke-2, dosen terlebih dahulu mengisi jurnal dan mengecek kehadiran mahasiswa. Semua mahasiswa hadir pada kesempatan itu. Apersepsi ini dilakukan dengan cara memberikan beberapa pertanyaan kepada mahasiswa. Walaupun mahasiswa masih malu-malu mengacungkan tangan, akhirnya ada mahasiswa yang bernama Ni Putu Ayu Sintya Dewi menjawab pertanyaan dosen dengan menyampaikan bahwa materi yang diperoleh sebelumnya berkenaan dengan menulis teks pidato, informasi yang problematik dan/atau kontradiktif, dan langkah-langkah membuat sebuah teks pidato. Penambahan (penegasan) materi tersebut sudah dianggap cukup oleh dosen. Selanjutnya, dosen membagikan bacaan (berupa teks pidato) yang problematik dan kontroversi kepada mahasiswa. Teks yang diberikan kepada mahasiswa tersebut berupa sambutan Rektor Universitas Pendidikan Ganesha saat Dies Natalis ke-24 UNDIKSHA. Mahasiswa diminta untuk membaca teks tersebut.

Berdasarkan hasil analisis terhadap data observasi, skor aktivitas mahasiswa dapat direkapitulasi seperti tabel di bawah ini.

Tabel 1. Rekapitulasi Hasil Observasi Aktivitas Mahasiswa pada Siklus I

\begin{tabular}{|c|l|c|c|c|c|}
\hline No. & \multicolumn{1}{|c|}{ Aktivitas } & $\begin{array}{c}\text { Yang } \\
\text { melakukan }\end{array}$ & \% & $\begin{array}{c}\text { Yang tidak } \\
\text { melakukan }\end{array}$ & \% \\
\hline 1 & $\begin{array}{l}\text { Mahasiswa mendengarkan apersepsi } \\
\text { mengenai teks pidato dan langkah- } \\
\text { langkah menulis teks pidato }\end{array}$ & 9 & $60 \%$ & 6 & $40 \%$ \\
\hline 2 & $\begin{array}{l}\text { Mahasiswa mendengarkan tujuan } \\
\text { pembelajaran yang disampaikan oleh } \\
\text { dosen }\end{array}$ & 8 & $53 \%$ & 7 & $46 \%$ \\
\hline 3 & $\begin{array}{l}\text { Mahasiswa mendengarkan penjelasan } \\
\text { dosen mengenai materi pembeajaran }\end{array}$ & 9 & $60 \%$ & 6 & $40 \%$ \\
\hline 4 & $\begin{array}{l}\text { Mahasiswa membaca bacaann yang di } \\
\text { dalamnya ada permasalahan aktual }\end{array}$ & 10 & $67 \%$ & 5 & $33 \%$ \\
\hline 5 & $\begin{array}{l}\text { Mahasiswa berdiskusi dengan teman } \\
\text { sebangku mengenai permasalahan yang } \\
\text { diangkat }\end{array}$ & 9 & $60 \%$ & 6 & $40 \%$ \\
\hline 6 & $\begin{array}{l}\text { Mahasiswa membuat kerangka teks } \\
\text { pidato berupa sebuah kalimat topic }\end{array}$ & 5 & $33 \%$ & 10 & $67 \%$ \\
\hline 7 & $\begin{array}{l}\text { Mahasiswa membuat kerangka teks pi- } \\
\text { dato berupa beberapa kalimat penjelas }\end{array}$ & 5 & $33 \%$ & 10 & $67 \%$ \\
\hline 8 & $\begin{array}{l}\text { Mahasiswa melakukan pengembangan } \\
\text { penulisan teks pidato }\end{array}$ & 15 & $100 \%$ & - & - \\
\hline 9 & $\begin{array}{l}\text { Mahasiswa menukarkan pekerjaannya } \\
\text { untuk dikoreksi oleh teman sebangku }\end{array}$ & 15 & $100 \%$ & - & - \\
\hline 10 & $\begin{array}{l}\text { Mahasiswa melakukan revisi terhadap } \\
\text { tulisannya }\end{array}$ & 15 & $100 \%$ & - & - \\
\hline & Total & $\mathbf{1 0 0 0}$ & & & \\
\hline & Rata-rata aktivitas & & & \\
\hline & & & & \\
\hline
\end{tabular}

Berdasarkan hasil observasi, skor rata-rata aktivitas yang diperoleh mahasiswa pada siklus I adalah 10,0 dengan jumlah skor secara keseluruhan sebesar 100. Ini menunjukkan bahwa mahasiswa sangat aktif di kelas. 


\section{Hasil Belajar Mahasiswa}

Tabel 2. Hasil Belajar Mahasiswa pada Siklus I

\begin{tabular}{|l|l|l|}
\hline No. & \multicolumn{1}{|c|}{ Nama Mahasiswa } & Skor \\
\hline 1 & I Komang Widnyana & 70 \\
\hline 2 & Ni Luh Eka Sumiarti & 75 \\
\hline 3 & Ni Putu Ayu Sintya Dewi & 81 \\
\hline 4 & Ni Made Sauca Yukti & 80 \\
\hline 5 & Nyoman Trayanjana Putra & 65 \\
\hline 6 & Ni Putu Aprilia Wirmayanti & 76 \\
\hline 7 & I Putu Darmika & 70 \\
\hline 8 & Putu Herlyn Novita Dewi & 73 \\
\hline 9 & Ni Putu Ana Yuspidayanti & 75 \\
\hline 10 & Ni Luh Putu Gita Septiareni & 75 \\
\hline 11 & Ni Putu Kusma Dewi & 60 \\
\hline 12 & Abu Farhan & 68 \\
\hline 13 & Mochamad Dana Irwantha & 68 \\
\hline 14 & Putu Arya Mahendra & 75 \\
\hline 15 & Uul Sinthiawati & 61 \\
\hline & $\begin{array}{l}\text { Jumlah } \\
\text { Rata-rata } \\
\text { Ketuntasan Klasikal }\end{array}$ & $\begin{array}{l}\mathbf{1 0 7 2} \\
\mathbf{4 7 \%}\end{array}$ \\
\hline
\end{tabular}

Berdasarkan hasil evaluasi, rekapitulasi hasil belajar mahasiswa pada siklus I dapat dibuat seperti tabel 3 di bawah ini.

Tabel 3. Rekapitulasi hasil belajar mahasiswa pada siklus I

\begin{tabular}{|c|c|c|c|}
\hline No. & $\begin{array}{c}\text { Hasil Belajar } \\
\text { yang Dicapai }\end{array}$ & $\begin{array}{c}\text { J u m I a h } \\
\text { Mahasiswa }\end{array}$ & Persentase \\
\hline 1. & $50-60$ & 1 & $7 \%$ \\
\hline 2. & $50-70$ & 5 & $33 \%$ \\
\hline 3. & $75-100$ & 9 & $60 \%$ \\
\hline
\end{tabular}

Tabel 3 di atas menunjukkan bahwa 1 (7\%) mahasiswa memperoleh nilai di bawah angka 65 dan sebanyak 5 (33\%) mahasiswa belum mencapai nilai 75. Dengan kata lain, ketuntasan nilai menulis teks pidato dengan pola PBM baru dicapai oleh 9 (60\%) maha- siswa dengan ketuntasan klaksikal sebesar 47\%. Hasil evaluasi itu menunjukkan bahwa mahasiswa belum memenuhi standar nilai baik, yaitu 75 .

\section{Refleksi Proses Pembelajaran Siklus I}

Bertolok pada hasil pengamatan peneliti selama siklus I, ada beberapa hal yang perlu dicermati dalam penerapan model PBM dalam pembelajaran menulis teks pidato. Belum terpenuhinya nilai standar oleh mahasiswa disebabkan oleh perilaku mahasiswa yang kurang baik. Upaya lain yang dilakukan oleh dosen adalah menghadirkan bacaan yang lebih panjang dan komprehensif sehingga memuat masalah yang lebih jelas dan rinci. Bercermin dari siklus I yang bahan bacaannya sangat pendek, siklus II akan dihadirkan bacaan yang cukup panjang.

\section{Rencana Tindakan Siklus II}

Berdasarkan hasil refleksi pada siklus I, ada beberapa rencana tindakan yang akan dilakukan pada siklus II. Ini dilakukan untuk meningkatkan proses pembelajaran di kelas. Beberapa tindakan tersebut dapat diuraikan sebagai berikut.

1. Mahasiswa yang sering ribut dipindahkan ke tempat duduk paling depan oleh dosen untuk menghindari kegaduhan di kelas.

2. Mahasiswa diberikan kesempatan untuk menyiapkan alat-alat pembelajaran sebelum dosen memulai pembelajaran.

3. Mahasiswa dicek kehadirannya oleh dosen.

4. Mahasiswa mendengarkan apersepsi yang disampaikan oleh dosen.

5. Mahasiswa mendengarkan tujuan pembelajaran yang disampaikan oleh dosen, dan seterusnya.

\section{Siklus II}

Pembelajaran pada siklus II dilaksanakan mengacu pada rencana tindakan yang dihasilkan melalui refleksi pada akhir siklus I. Siklus II dirancang dalam satu kali pertemuan dengan alokasi waktu 2 x 40 menit. Materi yang diajarkan pada pertemuan yang dilaksanakan pada Rabu, 1 Juni 2016 ini mengenai menulis teks pidato dengan pola PBM. Aktivi- 
tas mahasiswa pada siklus II diobservasi melalui dua instrumen, yaitu catatan lapangan dan lembar observasi.

\section{Hasil Observasi}

Pembelajaran diawali dengan kegiatan membuka pembelajaran yang berlangsung kurang lebih lima menit. Selanjutnya, dosen menyampaikan tujuan pembelajaran agar mahasiswa lebih memahami rencana pembelajaran pada siklus II ini. Pembelajaran inti pada siklus II ditandai dengan penegasan materi pembelajaran, khususnya langkah-langkah membuat teks pidato. Dosen membagikan contoh tulisan teks pidato kepada mahasiswa. Dosen membahas contoh teks pidato tersebut secara jelas. Kejelasannya tampak pada upaya dosen untuk menjelaskan langkah-langkah dalam membuat kalimat topik, beberapa kalimat penjelas.

Pada siklus II ini mahasiswa langsung membaca bacaan yang diberikan oleh dosen. Mereka tampak serius membaca bacaan tersebut. Walaupun masih ada beberapa mahasiswa yang tampak mengobrol, mereka tidak sampai mengganggu proses pembelajaran di kelas. Setelah membaca bacaan, mahasiswa pun memulai membuat kerangka teks pidato. Sebagian besar mahasiswa sudah mengikuti aturan dalam membuat paragraf. Aktivitas mahasiswa berikutnya adalah berdiskusi dengan teman sebangkunya. Mahasiswa tampak lebih aktif berdiskusi dengan teman sebangkunya untuk mengoreksi tulisan yang sudah dibuat. Karena waktu yang disediakan terbatas untuk berdiskusi, akhirnya dosen menunjuk lima mahasiswa untuk menyampaikan informasi yang problematik dan/atau kontradiktif. Kelima mahasiswa tersebut dipilih oleh dosen berdasarkan hasil tes yang didapatkan pada siklus I.

Selanjutnya, dosen bersama mahasiswa menyimpulkan hasil pembelajaran. Selain itu, dosen juga menyuruh mahasiswa untuk mengisi angket.

Berdasarkan hasil analisis terhadap data observasi, skor aktivitas mahasiswa dapat direkapitulasi seperti Tabel 4 di bawah ini.

Tabel 4. Rekapitulasi Hasil Observasi Aktivitas Mahasiswa pada Siklus II

\begin{tabular}{|c|l|c|c|c|c|}
\hline No. & \multicolumn{1}{|c|}{ Aktivitas } & $\begin{array}{c}\text { Yang } \\
\text { melakukan }\end{array}$ & $\%$ & $\begin{array}{c}\text { Yang tidak } \\
\text { melakukan }\end{array}$ & $\%$ \\
\hline 1 & $\begin{array}{l}\text { Mahasiswa mendengarkan apersepsi } \\
\text { mengenai paragaf argumentasi dan } \\
\text { langkah-langkah menulis teks pidato }\end{array}$ & 13 & $87 \%$ & 2 & $13 \%$ \\
\hline 2 & $\begin{array}{l}\text { Mahasiswa mendengarkan tujuan } \\
\text { pembelajaran yang disampaikan oleh } \\
\text { dosen }\end{array}$ & 14 & $93 \%$ & 1 & $7 \%$ \\
\hline 3 & $\begin{array}{l}\text { Mahasiswa mendengarkan penjelasan } \\
\text { dosen mengenai materi pembeajaran }\end{array}$ & 15 & $89 \%$ & - & $11 \%$ \\
\hline 4 & $\begin{array}{l}\text { Mahasiswa membaca bacaann yang di } \\
\text { dalamnya ada permasalahan actual }\end{array}$ & 15 & $100 \%$ & - & - \\
\hline 5 & $\begin{array}{l}\text { Mahasiswa berdiskusi dengan teman } \\
\text { sebangku mengenai permasalahan yang } \\
\text { diangkat }\end{array}$ & 14 & $93 \%$ & 1 & $7 \%$ \\
\hline 6 & $\begin{array}{l}\text { Mahasiswa membuat kerangka teks } \\
\text { pidato berupa sebuah kalimat topic }\end{array}$ & 15 & $100 \%$ & - & - \\
\hline 7 & $\begin{array}{l}\text { Mahasiswa membuat kerangka teks pi- } \\
\text { dato berupa beberapa kalimat penjelas }\end{array}$ & 15 & $100 \%$ & - & - \\
\hline
\end{tabular}




\begin{tabular}{|c|l|c|c|c|c|}
\hline 8 & $\begin{array}{l}\text { Mahasiswa melakukan pengembangan } \\
\text { penulisan teks pidato }\end{array}$ & 15 & $100 \%$ & - & - \\
\hline 9 & $\begin{array}{l}\text { Mahasiswa menukarkan pekerjaannya } \\
\text { untuk dikoreksi oleh teman sebangku }\end{array}$ & 15 & $100 \%$ & - & - \\
\hline 10 & $\begin{array}{l}\text { Mahasiswa melakukan revisi draf teks } \\
\text { pidato yang sudah dibuatnya }\end{array}$ & 15 & $100 \%$ & - & - \\
\hline
\end{tabular}

Pada siklus II ini, aktivitas belajar mahasiswa sangat aktif. Hal itu dapat diamati saat kegiatan berlangsung. Tabel 4 tersebut juga menunjukkan bahwa ada sejumlah aktivitas yang belum dilakukan oleh mahasiswa di kelas, yakni sebanyak $2(13 \%)$ mahasiswa tidak mendengarkan apersepsi teks pidato dan langkah-langkah menulis teks pidato; sebanyak 1 (7\%) mahasiswa tidak mendengarkan tujuan pembelajaran; dan sebanyak 1 (7\%) mahasiswa tidak berdiskusi dengan teman sebangku mengenai permasalahan yang diangkat. Skor rata-rata aktivitas yang diperoleh mahasiswa mencapai 10. Ini menandakan aktivitas mahasiswa ada pada skor $X \geq 7,55$ atau berkategori sangat baik.

\section{Hasil Belajar Mahasiswa}

Seperti pembelajaran pada siklus I, mahasiswa juga dievaluasi pada siklus II. Pengevaluasian ini dilakukan untuk mengetahui tingkat kualitas teks pidato mahasiswa, setelah mereka membaca contoh teks pidato tersebut. Hasil belajar mahasiswa pada siklus II dapat diamati pada Tabel 5 di bawah ini.

Tabel 5. Hasil belajar mahasiswa pada siklus II

\begin{tabular}{|l|l|l|}
\hline No. & \multicolumn{1}{|c|}{ Nama Mahasiswa } & \multicolumn{1}{c|}{ Skor } \\
\hline 1 & I Komang Widnyana & 76 \\
\hline 2 & Ni Luh Eka Sumiarti & 77 \\
\hline 3 & Ni Putu Ayu Sintya Dewi & 95 \\
\hline 4 & Ni Made Sauca Yukti & 90 \\
\hline 5 & Nyoman Trayanjana Putra & 85 \\
\hline 6 & Ni Putu Aprilia Wirmayanti & 85 \\
\hline 7 & I Putu Darmika & 85 \\
\hline 8 & Putu Herlyn Novita Dewi & 80 \\
\hline 9 & Ni Putu Ana Yuspidayanti & 87 \\
\hline 10 & Ni Luh Putu Gita Septiareni & 84 \\
\hline 11 & Ni Putu Kusma Dewi & 75 \\
\hline 12 & Abu Farhan & 76 \\
\hline 13 & Mochamad Dana Irwantha & 82 \\
\hline 14 & Putu Arya Mahendra & 80 \\
\hline 15 & Uul Sinthiawati & 78 \\
\hline & Jumlah & $\mathbf{1 2 3 5}$ \\
\hline & Rata-rata & $\mathbf{8 2}$ \\
\hline & Ketuntasan Klasikal & $\mathbf{8 2 \%}$ \\
\hline
\end{tabular}

Berdasarkan hasil evaluasi, rekapitulasi hasil belajar mahasiswa pada siklus II dapat dibuat seperti Tabel 6 di bawah ini.

Tabel 6. Rekapitulasi Hasil Belajar Mahasiswa pada siklus II

\begin{tabular}{|c|c|c|c|}
\hline No. & $\begin{array}{c}\text { Hasil Belajar } \\
\text { yang Dicapai }\end{array}$ & $\begin{array}{c}\text { J u m I a h } \\
\text { Mahasiswa }\end{array}$ & Persentase \\
\hline 1. & $75-100$ & 15 & $100 \%$ \\
\hline
\end{tabular}

Hasil belajar mahasiswa meningkat pada siklus II. Pada siklus ini menunjukkan bahwa sebanyak 15 (100\%) mahasiswa sudah mencapai nilai standar dengan ketuntasan klasikal sebesar $82 \%$. Data tersebut menunjukkan bahwa semua $(15 / 100 \%)$ mahasiswa sudah mencapai nilai standar.

\section{Respons Mahasiswa terhadap Penerapan Model PBM dalam Pembelajaran Menulis Teks Pidato}

Respons mahasiswa dalam pembelajaran dikumpulkan berdasarkan angket respons yang diberikan pada akhir siklus II. Data respons diperoleh dari angket yang telah disebarkan kepada mahasiswa. Berdasarkan 
data angket yang diisi oleh mahasiswa, diperoleh rata-rata respons mahasiswa sebesar 19,0 (Setuju). Sementara itu, sebaran nilai respons mahasiswa pada masing-masing kategori yang telah ditetapkan dapat diamati pada Tabel 7 di bawah ini.

Tabel 7. Sebaran respons mahasiswa

\begin{tabular}{|c|l|c|c|c|c|c|}
\hline \multirow{2}{*}{ No. } & \multicolumn{1}{|c|}{ Pernyataan } & \multicolumn{5}{c|}{ Pendapat } \\
\cline { 3 - 7 } & & SS & S & R & TS & STS \\
\hline 1 & $\begin{array}{l}\text { Penerapan model PBM lebih meny- } \\
\text { enangkan dalam menulis teks pidato }\end{array}$ & $0 \%$ & $1(6 \%)$ & $0 \%$ & $1(6 \%)$ & $0 \%$ \\
\hline 2 & $\begin{array}{l}\text { Penerapan model PBM lebih efektif } \\
\text { dalam menulis teks pidato }\end{array}$ & $\begin{array}{c}15 \\
(100 \%)\end{array}$ & $\begin{array}{c}8 \\
(53 \%)\end{array}$ & $\begin{array}{c}13 \\
(87 \%)\end{array}$ & $\begin{array}{c}13 \\
(88 \%)\end{array}$ & $\begin{array}{c}7 \\
(74 \%)\end{array}$ \\
\hline 3 & $\begin{array}{l}\text { Penerapan model PBM dapat mening- } \\
\text { katkan kreativitas ketika menulis teks } \\
\text { pidato }\end{array}$ & $0 \%$ & $\begin{array}{c}6 \\
(40 \%)\end{array}$ & $\begin{array}{c}2 \\
(13 \%)\end{array}$ & $1(6 \%)$ & $\begin{array}{c}8 \\
(53 \%)\end{array}$ \\
\hline 4 & $\begin{array}{l}\text { Penerapan model PBM dapat menin- } \\
\text { gkatkan kekritisan ketika menulis teks } \\
\text { pidato }\end{array}$ & $0 \%$ & $0 \%$ & $0 \%$ & $0 \%$ & $0 \%$ \\
\hline 5 & $\begin{array}{l}\text { Penerapan model PBM dapat memoti- } \\
\text { vasi dalam menulis teks pidato }\end{array}$ & $0 \%$ & $0 \%$ & $0 \%$ & $0 \%$ & $0 \%$ \\
\hline
\end{tabular}

Keterangan

$$
\begin{array}{ll}
\text { SS } & \text { : sangat setuju } \\
\text { S } & \text { : setuju } \\
\text { R } & \text { : ragu-ragu } \\
\text { TS } & \text { : tidak setuju } \\
\text { STS } & \text { : sangat tidak setuju }
\end{array}
$$

Bertolok pada sebaran respons mahasiswa, sebanyak $15(100 \%)$ mahasiswa setuju bahwa penerapan model PBM lebih menyenangkan dalam menulis teks pidato. Pada pernyataan kedua, yakni penerapan model PBM lebih efektif dalam pembelajaran menulis teks pidato jika dibandingkan dengan pembelajaran sebelum penerapan model PBM di kelas; sebanyak 1 (6\%) mahasiswa memilih kategori sangat setuju; 8 (53\%) mahasiswa memilih kategori setuju; dan sebanyak $6(40 \%)$ mahasiswa ragu-ragu.

\section{Refleksi Proses Pembelajaran Siklus II}

Berdasarkan hasil observasi selama pelaksanaan tindakan siklus II, diperoleh perkembangan yang cukup signifikan, baik dalam hal proses maupun hasil pembelajaran.
Pembelajaran ini tidak hanya menanggulangi kendala-kendala yang muncul tetapi juga mempertahankan keunggulan-keunggulan dari pembelajaran yang telah berlangsung sebelumnya. Mahasiswa sangat aktif dalam mengikuti proses pembelajaran di kelas. Hasil belajar mahasiswa pada siklus II mengalami peningkatan. Secara keseluruhan, mahasiswa sudah mencapai nilai standar.

\section{Pembahasan}

Dari uraian hasil penelitian di atas, penelitian ini memiliki tujuan menemukan langkah-langkah pembelajaran dengan model PBM yang dapat meningkatkan keterampilan menulis teks pidato mahasiswa semester III kelas A Jurusan Pendidikan Bahasa dan Sastra Indonesia. Langkah-langkah pembelajaran dengan model PBM yang tepat yang dapat meningkatkan keterampilan menulis teks pidato mahasiswa itu seperti berikut.

1. Mahasiswa yang sering ribut dipindahkan ke tempat duduk paling depan oleh dosen.

2. Mahasiswa diberikan kesempatan untuk menyiapkan alat-alat pembelajaran sebelum 
dosen memulai pembelajaran.

3. Mahasiswa mendengarkan apersepsi dan tujuan pembelajaran yang disampaikan oleh dosen.

4. Mahasiswa memperhatikan contoh teks pidato yang diberikan oleh dosen dan mendengarkan penegasan dosen mengenai teks pidato yang ditulis berdasarkan permasalahan yang ada.

5. Mahasiswa menyimak penegasan dosen berkenaan dengan penulisan teks pidato yang harus diawali dengan kegiatan membaca permasalahan/memahami permasalahan, menempuh proses berpikir, dan menggunakan waktu seefektif mungkin.

6. Mahasiswa memahami permasalahan yang ada pada bacaan.

7. Mahasiswa mendiskusikan permasalahan yang ada dan menemukan solusi berupa argumentasi-argumentasi.

8. Mahasiswa menuliskan argumentasi-argumentasi dalam kerangka paragraf, berupa sebuah kalimat topik dan beberapa kalimat penjelas.

9. Mahasiswa mengembangkan kerangka karangannya. Memperhatikan organisasi antarkalimat, memilih diksi yang baik, bahasa yang baik, dan teknik penulisan yang baik.

10. Mahasiswa menukarkan pekerjaannya agar dikoreksi oleh teman sebangkunya.

11. Mahasiswa melakukan revisi terhadap tulisan yang dibuat atas saran atau masukan teman sebangku.

12. Mahasiswa mengumpulkan tulisan teks pidato kepada dosen.

13. Mahasiswa bersama dosen menyimpulkan hasil pembelajaran.

Langkah-langkah tersebut dapat meningkatkan keterampilan menulis teks pidato mahasiswa semester III kelas A Jurusan Pendidikan Bahasa dan Sastra Indonesia. Data yang ada menunjukkan bahwa sebanyak 15 $(100 \%)$ mahasiswa mencapai nilai standar. Ada beberapa langkah yang memiliki peran penting dalam meningkatkan keterampilan menulis teks pidato mahasiswa itu. Pertama, penerapan model PBM dalam pembelajaran menulis teks pidato menuntut mahasiswa un- tuk menempuh proses berpikir. Itu tidak terlepas dari fungsi model PBM sebagai alat untuk melatih kekritisan berpikir. Penulisan teks pidato dengan model PBM yang menuntut proses berpikir memberikan pengaruh positif bagi mahasiswa. Mereka menjadi mampu mengetahui, menganalisis, menyintesis, dan memberikan evaluasi (penilaian) terhadap masalah.

Model PBM dalam hal itu mampu meningkatkan keterampilan menulis teks pidato mahasiswa sekaligus meningkatkan kekritisan mereka. Kekritisan mahasiswa tampak pada kecermatan (ketajaman) mereka dalam menganalisis masalah dan memberikan solusi dari masalah. Di samping meningkatkan kekritisan mahasiswa, kegiatan menulis teks pidato dengan model PBM yang menuntut proses berpikir juga mampu meningkatkan daya ingat mahasiswa terhadap isi bacaan atau masalah. Rusman (2010: 254) menyatakan bahwa model PBM dapat membangkitkan pemahaman mahasiswa terhadap masalah dan keinginan memecahkan masalah.

Selain itu, peningkatan keterampilan menulis teks pidato pada mahasiswa juga tidak terlepas dari kegiatan berdiskusi dengan teman sebangkunya. Keunggulan kegiatan berdiskusi model PBM dapat digunakan sebagai media yang efektif untuk bertukar pikiran berkenaan dengan pengetahuan atau pemahaman terhadap masalah pada mahasiswa. Adanya kegiatan bertukar pikiran membuat mereka memiliki pemahaman yang lebih komprehensif mengenai isi bacaan atau masalah.

Selain meningkatkan pemahaman bacaan terhadap mahasiswa, langkah-langkah pembelajaran menulis teks pidato dengan model PBM secara tepat juga dapat meningkatkan aktivitas mahasiswa. Keunggulan model PBM adalah memberikan kebebasan kepada mahasiswa dalam menuangkan ide dan pikiran kritisnya, dalam wujud kalimatkalimat yang terorganisasikan dengan baik. Dampak posistif langkah-langkah menulis teks pidato secara tepat bagi mahasiswa adalah mahasiswa menjadi sangat aktif, kreatif, dan senang di kelas. Aktivitas belajar mahasiswa mencapai 10. 
Peningkatan pemahaman terhadap bacaan dan aktivitas belajar mahasiswa juga didukung oleh respons mahasiswa yang setuju dengan penerapan model PBM dalam pembelajaran menulis teks pidato. Berdasarkan data angket yang diisi oleh mahasiswa, diperoleh rata-rata respons mahasiswa sebesar 19,0. Ada beberapa alasan yang menyebabkan mahasiswa setuju dengan penerapan model PBM. Alasan yang pertama adalah model PBM lebih menyenangkan dalam pembelajaran menulis teks pidato. Alasan kedua adalah model PBM lebih efektif dalam menulis teks pidato karena masalah yang ada pada bacaan lebih mudah dan menginspirasi mahasiswa dalam melahirkan gagasan. Alasan ketiga adalah model PBM dapat meningkatkan kreativitas mahasiswa. Alasan keempat adalah model PBM dapat meningkatkan kekritisan mahasiswa ketika menulis teks pidato. Alasan yang terakhir adalah model PBM dapat memotivasi mahasiswa dalam menulis. Mereka termotivasi untuk memecahkan masalah berangkat dari masalah menarik yang perlu mereka tanggapi dan atasi.

\section{PENUTUP}

\section{Simpulan}

Berdasarkan pembahasan di atas, penerapan langkah-langkah pembelajaran dengan model PBM yang tepat dapat meningkatkan keterampilan menulis teks pidato mahasiswa kelas A Jurusan Pendidikan Bahasa dan Sastra Indonesia. Langkah-langkah pembelajaran dengan model PBM yang tepat yang dapat meningkatkan keterampilan menulis teks pidato mahasiswa adalah sebagai berikut.

1. Mahasiswa yang sering ribut dipindahkan ke tempat duduk paling depan oleh dosen untuk menghindari kegaduhan di kelas.

2. Mahasiswa diberikan kesempatan untuk menyiapkan alat-alat pembelajaran. Di samping itu, mahasiswa juga mendengarkan penegasan dari dosen bahwa mereka harus mempersiapkan alat-alat pembelajaran sebelum dosen memasuki ruangan.

3. Mahasiswa dicek kehadirannya oleh dosen.

4. Mahasiswa mendengarkan apersepsi yang disampaikan oleh dosen.

5. Mahasiswa mendengarkan tujuan pembelajaran yang disampaikan oleh dosen.

6. Mahasiswa memperhatikan contoh kalimat topik, kalimat penjelas, dan teks pidato yang dibuat oleh dosen.

7. Mahasiswa menyimak penjelasan dosen mengenai langkah-langkah menulis teks pidato berdasarkan masalah.

8. Mahasiswa menyimak penegasan dosen berkenaan dengan pembuatan teks pidato berdasarkan masalah yang harus diawali dengan kegiatan membaca secara intensif.

9. Mahasiswa mendengarkan penegasan dosen mengenai pentingnya menggunakan waktu yang seefektif mungkin.

10. Mahasiswa membaca bacaan yang mengandung permasalahan secara intensif.

11. Mahasiswa membuat teks pidato berdasarkan masalah mengikuti langkah-langkah di bawah ini.

a. Mahasiswa memulai menulis teks pidato dengan membuat kerangka paragraf yang di dalamnya terdapat satu kalimat topik dan beberapa kalimat penjelas. Kalimat topik dan beberapa kalimat penjelas yang dibuat merupakan bentuk argumantasi terhadap permasalahan yang diangkat dalam bacaan. b. Mahasiswa mengembangkan kerangka paragraf dengan memperhatikan organisasi, pilihan kata (diksi), bahasa, dan teknik penulisan yang benar.

c. Mahasiswa memeriksa tulisan teman sebangkunya. Mereka akan menilai dari isi, organisasi, bahasa, diksi, dan teknik penulisan, pada tulisan yang dimiliki temannya.

d. Mahasiswa melakukan revisi terhadap tulisan yang sudah diberikan masukan oleh temannya.

Selain dapat meningkatkan keterampilan menulis teks pidato pada mahasiswa, langkahlangkah pembelajaran dengan model PBM yang tepat juga dapat meningkatkan aktivitas belajar mahasiswa di kelas. Peningkatan aktivitas itu didukung oleh respons mahasiswa yang setuju terhadap penerapan model PBM. 


\section{Saran}

Berdasarkan pemaparan mengenai hasil penelitian dan simpulan, terdapat dua saran yang dapat disampaikan dalam penelitian ini. Dosen Bahasa Indonesia diharapkan menerapkan model PBM dalam pembelajaran bahasa Indonesia sesuai dengan rancangan tindakan yang telah disampaikan dan diterapkan oleh peneliti. Berkenaan dengan hal itu, peneliti lainnya sangat diharapkan untuk melakukan penelitian mengenai model PBM dari aspek lain yang dianggap penting untuk dikaji, seperti hambatan penerapan model PBM dalam pembelajaran menulis teks pidato.

\section{DAFTAR PUSTAKA}

Abizar, Haris. 2010. Menulis, Kunci Raih Emotional, Spiritual, dan Intelektual Quotient. Jurnal Pewara Dinamika UNY, Vol. 11, No. 28, Maret 2010.

Hamalik, Oemar. 2004. Proses Belajar Mengajar. Jakarta: PT Bumi Angkasa.

Haris, Abdul. 2007. "Penerapan Metode Permainan Simulasi untuk Meningkatkan Kemampuan Berbicara pada Mahasiswa Kelas V Sekolah Dasar Negeri No. 1 Banjar Tegal Singaraja". Skripsi (tidak diterbitkan). Undiksha.

Sadia. 2006. Model Pembelajaran Berbasis Masalah (Pembelajaran Berdasarkan Paradigma Konstruktruktivisme. Undiksha. Makalah tidak diterbitkan.

Tarigan, Henry Guntur. 1994. Menulis sebagai Suatu Keterampilan Berbahasa. Bandung: Penerbit Angkasa.

Yelfiza. 2010. Managing The students' Interaction Teaching Reading Through Task-Based Learning. Jurnal Didaktika, Volume 3, Nomor 2, Juli 2010. 